\title{
Food and Feeding Habits of Three Cichlid Species Inhabiting Damietta Branch of the River Nile, Egypt
}

\author{
Kariman Sh. Shalloof ${ }^{1}-$ Mohammad N. Authman ${ }^{2}$ and \\ Midhat A. El-Kasheif ${ }^{1}$ \\ 1- National Institute of Oceanography and Fisheries, \\ 101 Kaser El- Eini St. Egypt. \\ 2- Department of Hydrobiology, National Research Center, \\ Dokki 12622, Giza, Egypt.
}

\begin{abstract}
$\mathrm{T}$ he present study is concerned with the seasonal analysis of the stomach contents of three species of cichlid fishes inhabiting Damietta branch of the River Nile, Egypt, namely Oreochromis niloticus (Linn., 1758), Sarotherodon galilaeus (Linn., 1758) and Tilapia zillii (Gerv., 1848). The natural food was studied from the stomach contents of fish ranging from 12-29, 11- 24 and 10- 21 $\mathrm{cm}$ in total length of the previous species, respectively. Stomach contents were analyzed using the frequency of occurrence and Percentage of composition methods. Additionally, feeding intensity, index of relative importance (IRI) and selectivity index (S) were calculated. The results showed that, food from plant origin dominates the diet of the three studied species and occurred frequently in more than $60.0 \%$ of the examined stomach. Values of IRI emphasized the importance of diatoms, blue green and green algae as major food resources in the stomach of $O$. niloticus followed by rotifers and organic detritus. S. galilaeus and T. zillii followed nearly the same trend as O. niloticus, but plant tissues follow blue green and green algae in the diet of $T$. zillii. IRI indicates also the importance of food of animal origin in the diets of O. niloticus and S. galilaeus than $T$. zillii. The feeding intensity is strongly influenced by season, since the highest stomach fullness occurred during summer. In conclusion, Cichlid fish species in Damietta Branch of River Nile are omnivorous, and did not consume food at random but have the ability to select and choose the preferred food stuff even during different seasons. These seasonal variations in preferred food makes the intraspecific competition between these species very low.
\end{abstract}

Key words: River Nile, Damietta branch, O. niloticus, S. galilaeus, T. zillii, feeding habits, feeding intensity, frequency of occurrence.

\section{INTRODUCTION}

River Nile is considered as the longest river in the world. In Egypt, the Nile extends for about $950 \mathrm{~km}$ from Aswan High Dam to Cairo. Then, the Nile is divided into two branches, the Rosetta and the Damietta branches; each branch 
is about $200 \mathrm{~km}$ in length and finally reaches the Mediterranean Sea (Raslan and Abdelbary, 2001).

Damietta branch of the River Nile has a great vital importance, since it serves as a source of water for municipal, industrial, agricultural and navigation. Damietta branch is passed to cut four governorates of length about $242 \mathrm{~km}$ with average width of $200 \mathrm{~m}$ and average depth of 12-20 m (Elewa and Ali, 1999).

Food is the main source of energy and plays an important role in determining the population levels, rate of growth and condition of fishes (Begum et al., 2008), and also the availability and distribution of food resources are the main factors that affected the distribution of fish (Mohsin et al., 1987 and 1988). Changes in the quantity and quality of natural feeds could be attributed to many important factors include time of feeding, kinds of food available, kind of digestive enzyme in the gut, life history stage, morphological changes in feeding apparatus due to age and the locality in which the fishes are found (Imevbore and Bakare, 1970; Ikusemiju and Olaniyan, 1977; Fagade, 1978; Akinwumi, 2001, Ogbeibu and Ezeunara, 2005). Data on different food items consumed by fish may eventually result in identification of stable food preference and in certain of trophic models as a tool to understand complex ecosystem (LopezPeralta and Arcilla, 2002; Bachok et al., 2004).

Since studies on the feeding habits of tilapia in the River Nile are scarce, and because food and feeding habits of fishes have a great significance in aquaculture practice, and helps to select such species of fishes for culture which will utilize all the available potential food of water bodies without any competition with one another but will live in association with other fishes (Begum et al., 2008), therefore, the objective of the present study was intended to examine the natural food needed by three cichlid species during different seasons in Damietta branch of the River Nile.

\section{MATERIAL AND METHODS}

A total of 1376, 1128 and 1190 specimens of O. niloticus, S. galilaeus and T. zillii, respectively were seasonally collected from commercial catches from autumn 2005 till summer 2006, from six stations covering Damietta branch of River Nile namely El-Kanater, Benha, El-Mansoura, Talkha, Faraskour and Damietta as shown in Fig. (1). Samples were collected by the most common fishing gears used in the River Nile, which are locally named as Ghazl El-Mehair, which consists of three layers (trammel net) and other fishing methods which locally named as El- Radakhah and El- Nakaria gears.

In laboratory, fish were identified and weighed to the nearest gm and measured to the nearest $\mathrm{mm}$ total length individually. Fish were then dissected and the stomachs were preserved in $10 \%$ formalin. Later, stomachs were opened and their degree of fullness were determined by an average visual estimate of fullness of all the stomach. 


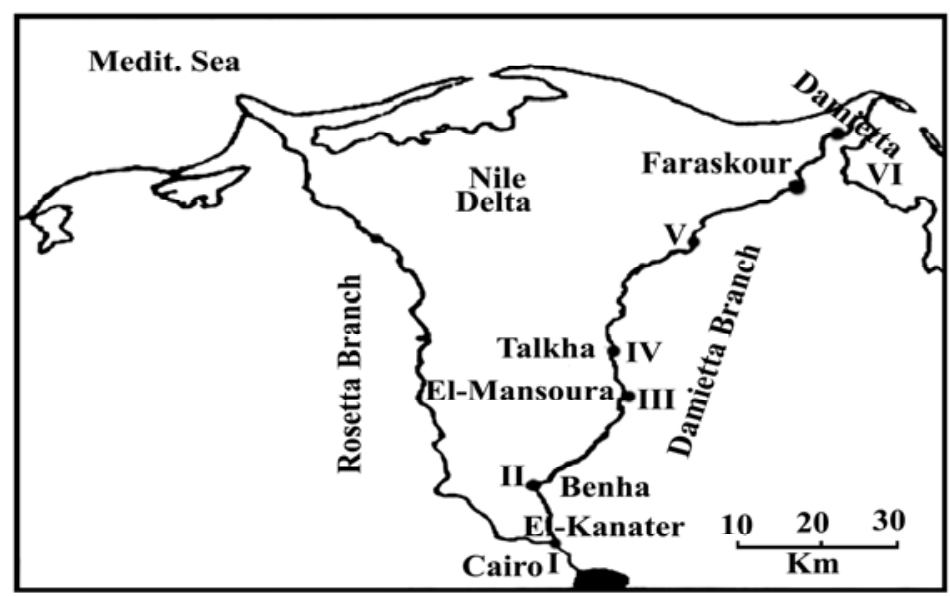

Fig. (1): Amap showing sampling stations in Damietta branch of the River Nile, Egypt.

The degree of stomach fullness is divided into 3 classes ranging from empty; half to full. Then the stomachs contents were examined using a research microscope and the different food items were identified according to Needham $\&$ Needham (1962). The results were analysed by employing two methods, the frequency of occurrence and Percentage of composition methods. In the frequency of occurrence method, the occurrence of food items was expressed as the percentage of the total number of stomach containing food (\% FO). This method requires minimum time and equipments and is simple to apply when stomach contents are readily identifiable (Ibrahim et al., 2003). In the Percentage of composition method, the number of each food item was expressed as the percentage of the total number of food items found in the stomach $(\% \mathrm{~N})$ (Hyslop, 1980).

An estimate of index of relative importance (IRI) of each food category was obtained by multiplying $\% \mathrm{FO}$ by $\% \mathrm{~N}$, from modified equation given by Laroche (1982), and used by Abdel- Aziz and Gharib (2007).

The selectivity index for different food items was calculated according to Berhaut (1973) equation: Selectivity index $(S)=n / N E$, where $n$ is the number of stomachs containing a certain food item and NE is the total number of examined stomachs. The obtained data was analyzed using the computer programmed Microsoft Excel, ver., 2003.

This study was conducted as a part of a research project titled "environmental and fisheries development of River Nile ", and was sponsored by the National Institute of Oceanography and Fisheries, Egypt. 


\section{Seasonal variations in the food items:}

\section{RESULTS}

The analysis of stomach contents in the present study demonstrated that, percentage of occurrence and Percentage of composition analysis showed great seasonal diversity in the food items of $O$. niloticus, S. galilaeus and T. zillii as obvious in Figs. (2-7). The main algal species belong to green (Chlorophyceae), blue green algae (Cyanophyceae), diatoms (Bacillariophyceae), flagellates (Euglenophyceae), higher plant tissues (macrophytes), and detritus constituted the food of plant origin, whereas, rotifers (Brachionus, Keratella, Polyarthera and Diglena), animal derivatives (fish scale, eggs, unidentified larvae, crustaceans and insect appendages,...etc.), nematode worms, copepods, ostracods, Cladocera (Bosmina, Diphanosoma, and Moina) and Mollusca constituted food of animal origin of the three studied species.

Generally, these figures show that, food from plant origin dominates the diet of the three studied species and occurred frequently in more than $60.0 \%$ of examined stomachs, and rotifers constituted the main occurred and Percentage of composition analyzed food of animal origin.

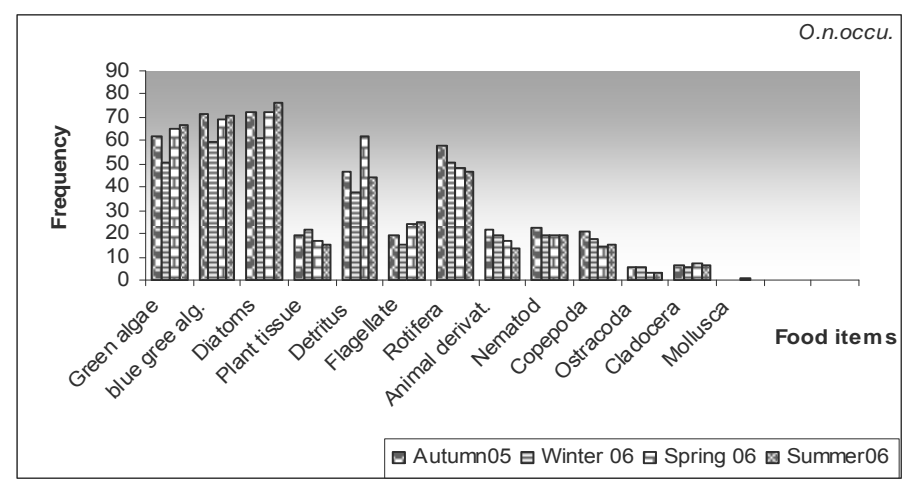

Fig. (2): Seasonal occurrence of different food items of O. niloticus in Damietta branch of the River Nile.

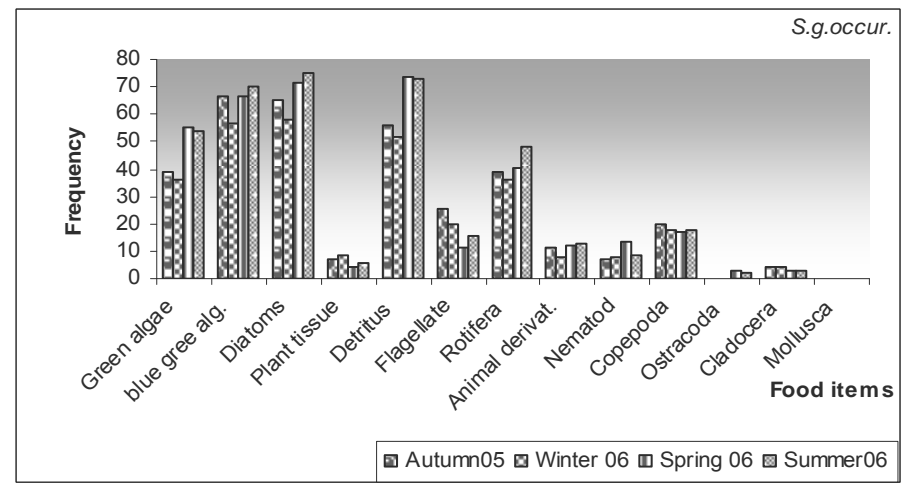

Fig. (3): Seasonal occurrence of different food items of S. galilaeus in Damietta branch of the River Nile. 


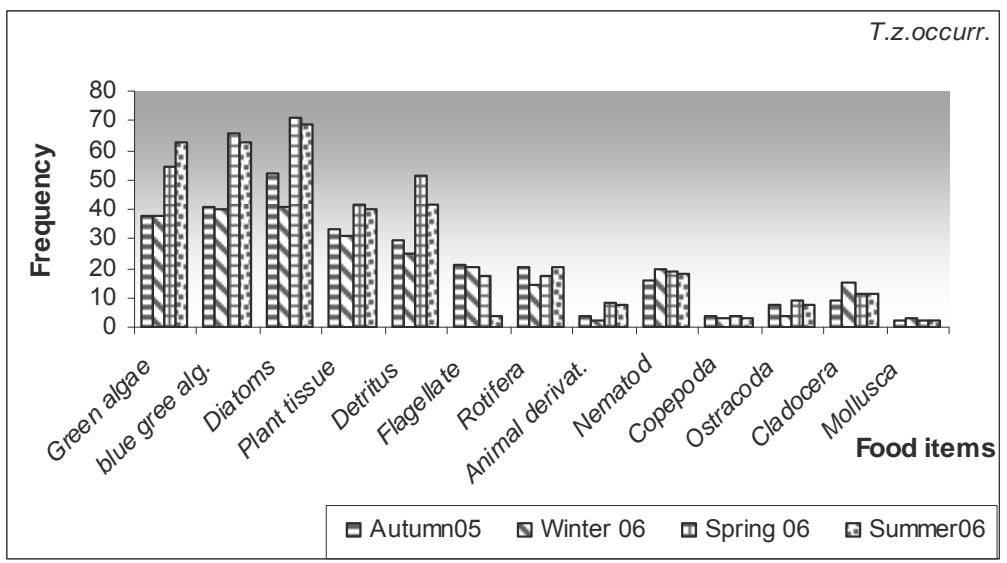

Fig. (4): Seasonal occurrence of different food items of T. zillii in Damietta branch of the River Nile.

The maximum occurrence and Percentage of composition analysis of green, blue green algae, diatoms and organic detritus were recorded during summer and spring for the three studied species as shown in Figs. (2-7). Flagellates were more represented during autumn and winter in the stomachs of S. galilaeus and T. zillii ( $25.3 \& 19.5$ and $20.4 \& 21.26 \%$, respectively); whereas it mostly occurred in the stomachs of $O$. niloticus during summer and spring (23.72 and $24.81 \%$, respectively). Higher plant tissues were higher frequently occurred in the stomachs of $T$. zillii than the other two studied species $(33.28$, $30.97,41.83$ and $40.27 \%$ ) during autumn, winter, spring and summer, respectively.

Generally, food of animal origin were more represented in the stomachs of $O$. niloticus and S. galilaeus than recorded in $T$. zillii calculated by frequency of occurrence and Percentage of composition methods all over the year as shown in Figs.( 2-7).

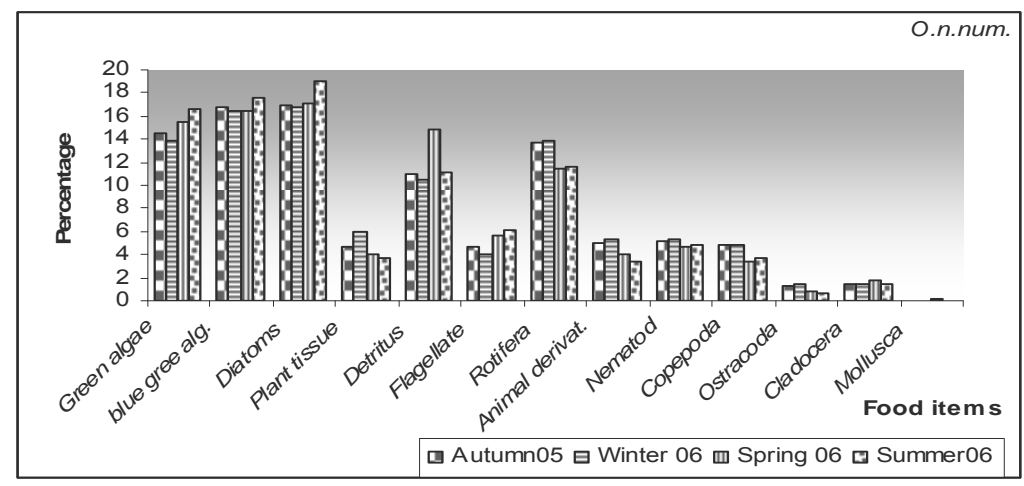

Fig. (5): Percentage of composition analysis of different food items of $O$. niloticus during different season in Damietta branch of the River Nile. 


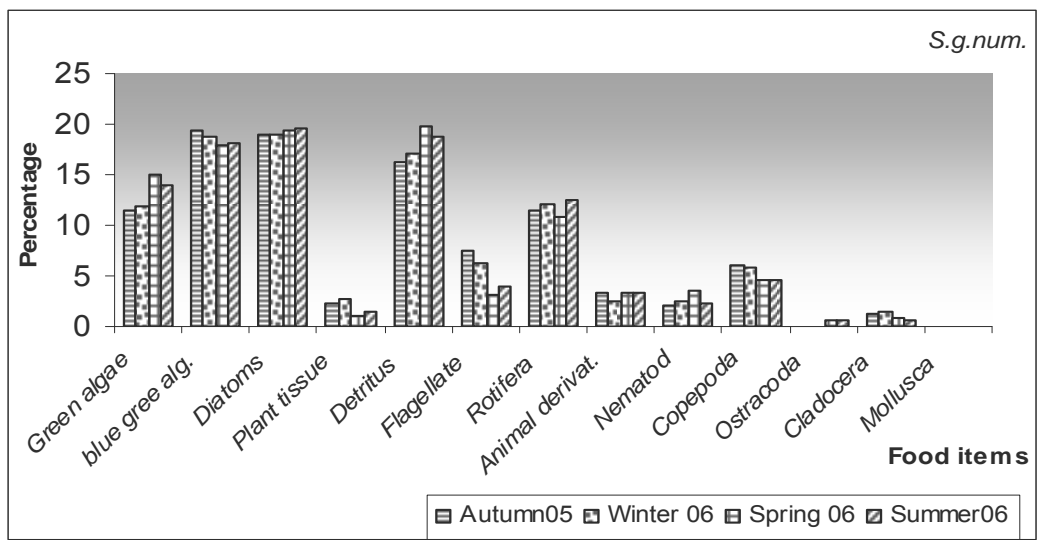

Fig. (6): Percentage of composition analysis of different food items of S. galilaeus during different season in Damietta branch of the River Nile.

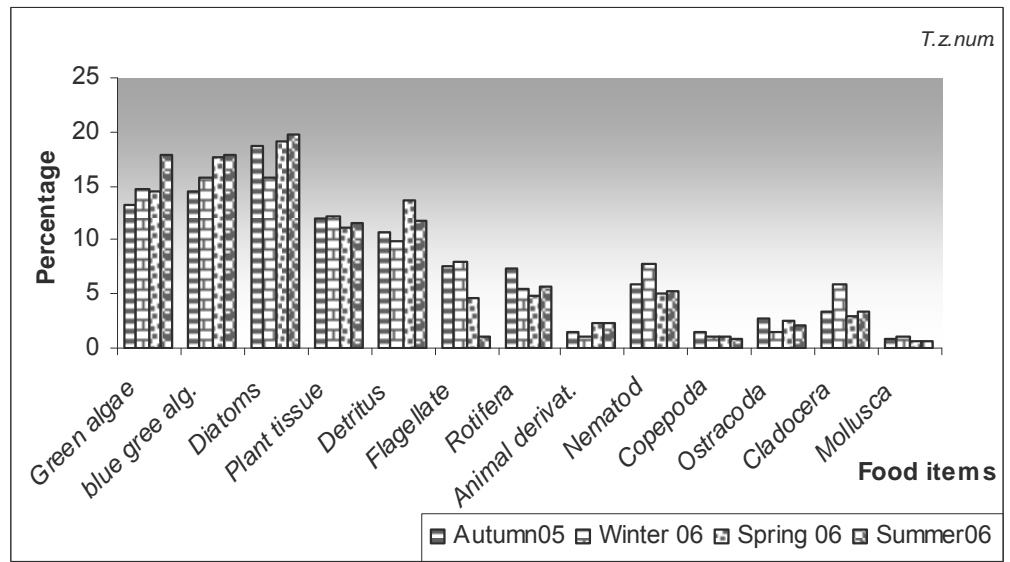

Fig. (7): Percentage of composition analysis of different food items of T. zillii during different season in Damietta branch of the River Nile.

\section{Index of relative importance (IRI):}

Results of the two methods of analyses (Index of relative importance, IRI) emphasized the importance of diatoms (1446.3, 1232.7, 1224.5 and 1027.7), blue green algae (1232.7, 1130.9, 1197.5 and 979.0), green alge (1109.2, 999.6, 905.1 and 701.7 during summer, spring, autumn and winter, respectively), as a major food resources in the stomach of $O$. niloticus, followed by rotifers and organic detritus as shown in Fig. ( 8). S. galilaeus and T. zillii followed nearly the same pattern as $O$. niloticus, but plant tissues followed blue green and green algae in the diet of $T$. zillii constituting (469.8, 462.5, 399.0 and 374.4) during spring, summer, autumn and winter, respectively as shown in Fig. (10). Also, among the food of animal origin, rotifers constitute the main food of animal origin in the stomachs of the three studied species, followed by nematode worms and animal derivatives especially during winter and autumn for O. niloticus, 
Copepoda for S. galilaeus especially during winter and autumn and nematode $\&$ Cladocera for T. zillii especially during winter (Figs. 8-10).

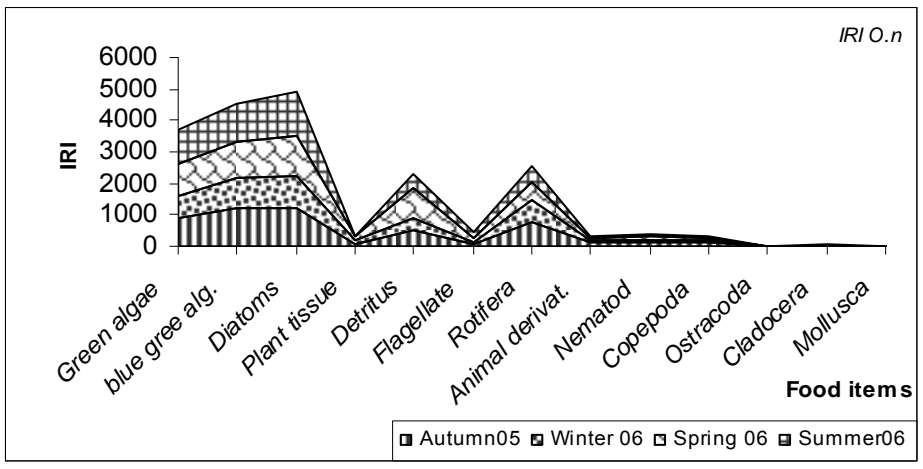

Fig. (8): Index of relative importance (IRI) of different food items of $O$. niloticus during different seasons in Damietta branch of the River Nile.

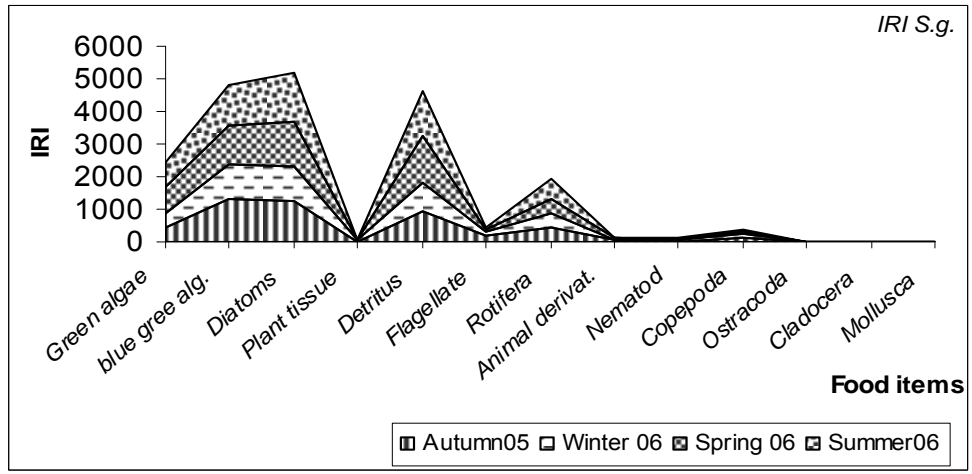

Fig. (9): Index of relative importance (IRI) of different food items of S. galilaeus during different seasons in Damietta branch of the River Nile.

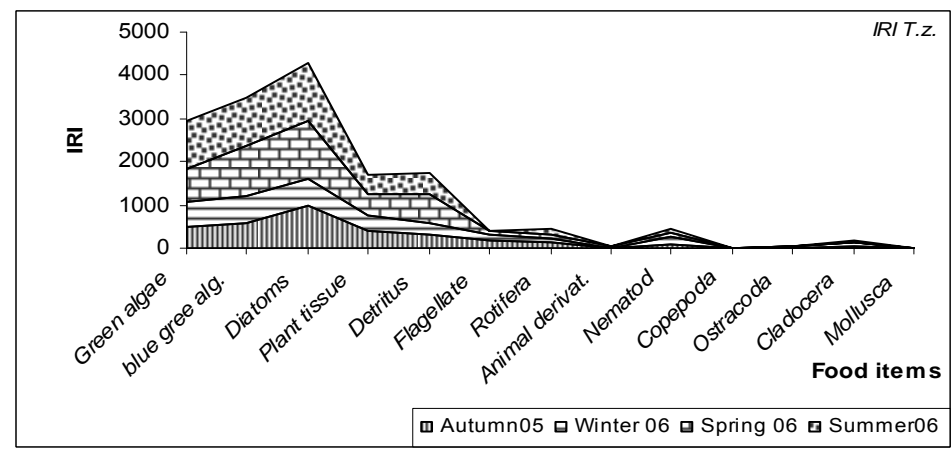

Fig. (10): Index of relative importance (IRI) of different food items of T. zillii during different seasons in Damietta branch of the River Nile. 
Values of IRI indicated also the importance of food of animal origin in the diets of O. niloticus and S. galilaeus than T. zillii (Figs. 8-10).

\section{Feeding intensity:}

Out of the 1376, 1128 and 1190 specimens of O. niloticus, S. galilaeus and T. zillii examined, $1032(75 \%), 878(77.84 \%)$ and $886(74.45 \%)$ of the previous species, respectively had food in their stomachs as shown in Tables (1, 2 and 3 ), respectively.

The highest percentage of empty stomachs for the three studied species was recorded during winter, since it constitutes $36.00,31.91$ and $52.24 \%$ of $O$. niloticus, S. galilaeus and T. zillii, respectively ( Tables 1, 2 and 3).

The results show that, the feeding intensity is strongly influenced by season and corresponding with the time of highest temperature, since the highest stomach fullness occurred during summer $(45.27,48.28$ and $44.96 \%$ for $O$. niloticus, S. galilaeus and T. zillii, respectively), and the recorded stomachs containing food was observed during spring and summer $(80.50$ and $79.17 \%$, respectively) for S. galilaeus; during autumn and summer (86.49 and 78.07\%, respectively) for $T$. zillii, and nearly the same value during autumn and summer (83.12 and 82.07\%, respectively) for O. niloticus (Tables 1-3).

Table (1): Seasonal percentage of feeding intensity of O. niloticus in Damietta branch of the River Nile (Percentage in brackets).

\begin{tabular}{|c|c|c|c|c|c|}
\hline Season & Empty & Half & Full & $\begin{array}{c}\text { Stomach } \\
\text { containing food }\end{array}$ & Total \\
\hline Autumn & $\begin{array}{c}27 \\
(16.88)\end{array}$ & $\begin{array}{c}66 \\
(41.25)\end{array}$ & $\begin{array}{c}67 \\
(41.88)\end{array}$ & $\begin{array}{c}133 \\
(83.12)\end{array}$ & $\begin{array}{c}160 \\
(11.63)\end{array}$ \\
\hline Winter & $\begin{array}{c}54 \\
(36.00)\end{array}$ & $\begin{array}{c}71 \\
(47.3)\end{array}$ & $\begin{array}{c}25 \\
(16.67)\end{array}$ & $(64.0)$ & $\begin{array}{c}150 \\
(10.90)\end{array}$ \\
\hline Spring & $\begin{array}{c}161 \\
(32.39)\end{array}$ & $\begin{array}{c}205 \\
(41.25)\end{array}$ & $\begin{array}{c}131 \\
(26.36)\end{array}$ & $\begin{array}{c}336 \\
(67.61)\end{array}$ & $\begin{array}{c}497 \\
(36.12)\end{array}$ \\
\hline Summer & $\begin{array}{c}102 \\
(17.93)\end{array}$ & $\begin{array}{c}210 \\
(36.91)\end{array}$ & $\begin{array}{c}257 \\
(45.17)\end{array}$ & $\begin{array}{c}467 \\
(82.07)\end{array}$ & $\begin{array}{c}569 \\
(41.35)\end{array}$ \\
\hline Total & $\begin{array}{c}344 \\
(25.0)\end{array}$ & $\begin{array}{c}552 \\
(40.12)\end{array}$ & $\begin{array}{c}480 \\
(34.88)\end{array}$ & $\begin{array}{c}1032 \\
(75.0)\end{array}$ & $\begin{array}{c}1376 \\
(100.0)\end{array}$ \\
\hline
\end{tabular}

Table (2): Seasonal percentage of feeding intensity of S. galilaeus in Damietta branch of the River Nile (Percentage in brackets).

\begin{tabular}{|c|c|c|c|c|c|}
\hline Season & Empty & Half & Full & $\begin{array}{c}\text { Stomach } \\
\text { containing food }\end{array}$ & Total \\
\hline Autumn & $\begin{array}{c}35 \\
(24.48)\end{array}$ & $\begin{array}{c}49 \\
(34.26)\end{array}$ & $\begin{array}{c}59 \\
(41.26)\end{array}$ & $\begin{array}{c}108 \\
(75.52)\end{array}$ & $\begin{array}{c}143 \\
(12.68)\end{array}$ \\
\hline Winter & $\begin{array}{c}45 \\
(31.91)\end{array}$ & $\begin{array}{c}70 \\
(49.65)\end{array}$ & $\begin{array}{c}26 \\
(18.44)\end{array}$ & $\begin{array}{c}96 \\
(68.09)\end{array}$ & $\begin{array}{c}141 \\
(12.5)\end{array}$ \\
\hline Spring & $\begin{array}{c}85 \\
(19.50)\end{array}$ & $\begin{array}{c}178 \\
(40.83)\end{array}$ & $\begin{array}{c}173 \\
(39.68)\end{array}$ & $\begin{array}{c}351 \\
(80.50)\end{array}$ & $\begin{array}{c}436 \\
(38.65)\end{array}$ \\
\hline Summer & $\begin{array}{c}85 \\
(20.83) \\
\end{array}$ & $\begin{array}{c}126 \\
(30.88) \\
\end{array}$ & $\begin{array}{c}197 \\
(48.28)\end{array}$ & $\begin{array}{c}323 \\
(79.17)\end{array}$ & $\begin{array}{c}408 \\
(36.17) \\
\end{array}$ \\
\hline Total & $\begin{array}{c}250 \\
(22.16)\end{array}$ & $\begin{array}{c}423 \\
(37.5)\end{array}$ & $\begin{array}{c}455 \\
(40.34)\end{array}$ & $\begin{array}{c}878 \\
(77.84)\end{array}$ & $\begin{array}{l}1128 \\
100.0\end{array}$ \\
\hline
\end{tabular}


Table (3): Seasonal percentage of feeding intensity of T. zillii in Damietta branch of the River Nile (Percentage in brackets).

\begin{tabular}{c|ccccc}
\hline \multirow{2}{*}{ Season } & Empty & Half & Full & $\begin{array}{c}\text { Stomach } \\
\text { containing } \\
\text { food }\end{array}$ & Total \\
\hline \multirow{2}{*}{ Autumn } & 20 & 66 & 62 & 128 & 148 \\
& $(13.51)$ & $(44.59)$ & $(41.89)$ & $(86.49)$ & $(12.44)$ \\
Winter & 70 & 46 & 18 & 64 & 134 \\
& $(52.24)$ & $(34.33)$ & $(13.43)$ & $(47.76)$ & $(11.26)$ \\
Spring & 114 & 177 & 161 & 338 & 452 \\
& $(25.22)$ & $(39.16)$ & $(35.62)$ & $(74.78)$ & $(37.98)$ \\
Summer & 100 & 151 & 205 & 356 & 456 \\
& $(21.93)$ & $(33.11)$ & $(44.96)$ & $(78.07)$ & $(38.32)$ \\
\hline \multirow{2}{*}{ Total } & 304 & 440 & 446 & 886 & 1190 \\
& $(25.55)$ & $(36.97)$ & $(37.48)$ & $(74.45)$ & $(100)$ \\
\hline
\end{tabular}

From the previous tables, it was also observed that, O. niloticus and $T$. zillii have highest percent of empty stomachs than $S$. galilaeus since nearly quarter of the examined samples of the former two species have empty stomachs.

\section{Selectivity index(S):}

Selectivity indices of different food items taken by O. niloticus, T. zillii and S. galilaeus during different seasons are shown in Figs. (11-13).

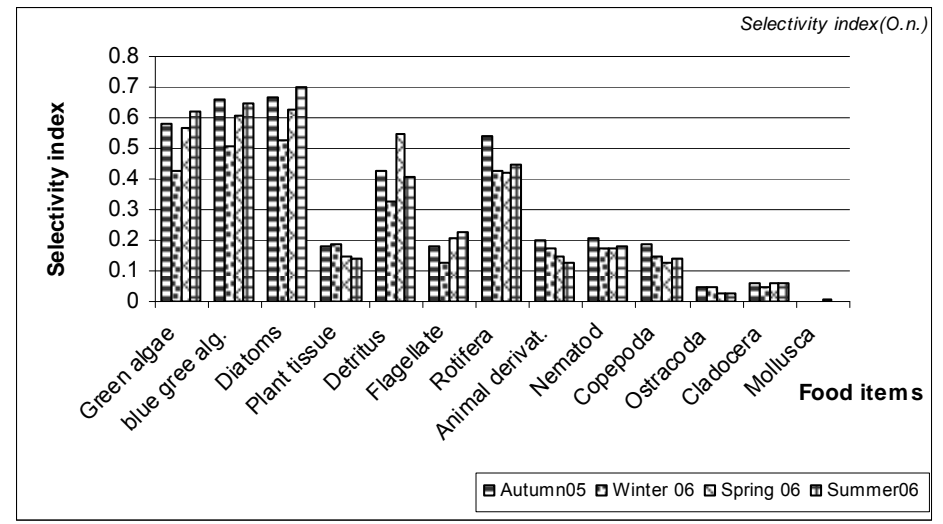

Fig. (11): Selectivity index of different food items of $O$. niloticus during different season in Damietta branch of the River Nile during the period of investigation. 


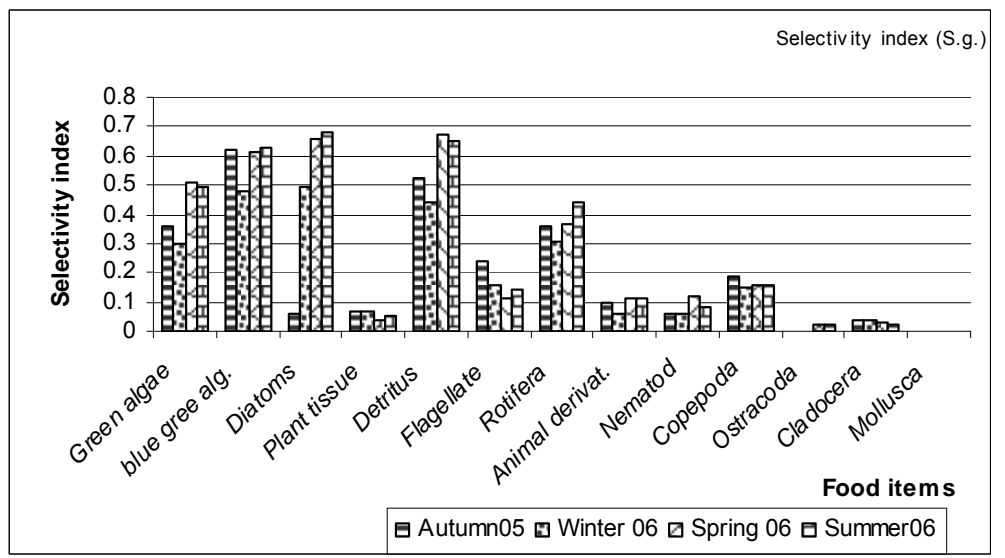

Fig. (12): Selectivity index of different food items of S. galilaeus during different season in Damietta branch of the River Nile during the period of investigation.

Seasonal variations in selectivity indices of different studied cichlid fish species show that the green, blue green algae and diatoms are the most important preferable food items (more than 0.5 ) obtained by O. niloticus and S. galilaeus all over the year, whereas $T$. zillii prefer blue green algae and diatoms during spring and summer only $(0.58 \& 0.55$ and $0.63 \& 0.61$ for both two food items, respectively) (Fig. 13).

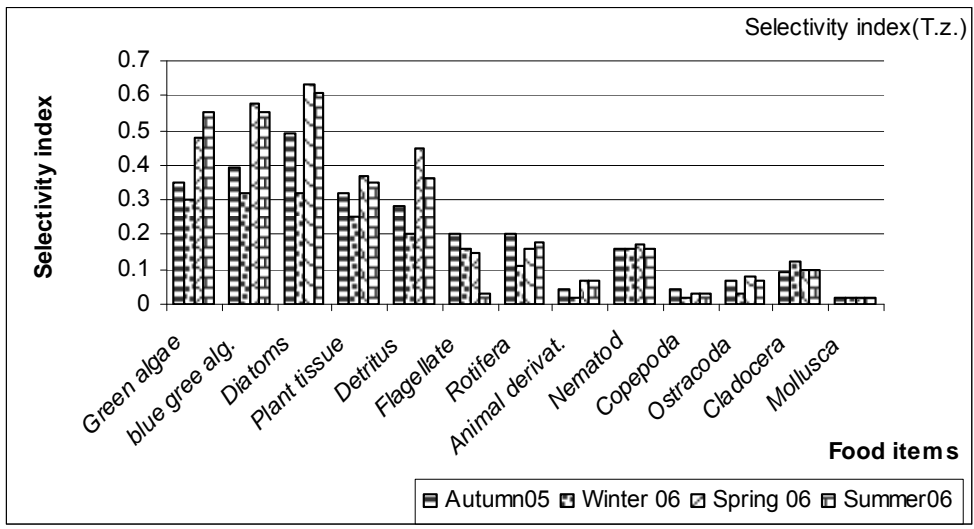

Fig. (13): Selectivity index of different food items of T. zillii during different season in Damietta branch of the River Nile during the period of investigation.

Higher plant tissues is the second preferable food item in the stomachs of O. niloticus and T. zillii (ranging from $0.14-0.19$ and $0.25-0.37$ for the previous species, respectively), whereas it considered as an accidental food items in the guts of S. galilaeus (0.04-0.07).

IRI values established detritus as the most preferable food item in the stomachs of $S$. galilaeus than the other two studied species in which they 
considered as a secondary item except during spring, since O. niloticus tend to select it. Flagellates ranked in the $2^{\text {nd }}$ items of importance $(0.11-0.24)$ all over the year for the three studied species except in summer, since it represented by the value 0.03 in the stomachs of T. zillii, whereas it considered as an accidental item.

Regarding the food of animal origin, rotifers are the preferable food in the stomachs of $O$. niloticus during autumn and summer (more than 0.5), whereas it ranked in the $2^{\text {nd }}$ rank of importance all over the year of the other two species (ranged from 0.11- 0.44). Animal derivatives, nematode worms and copepods are the second preferable foods of animal origin in the stomachs of $O$. niloticus during the four seasons except in winter, but $S$. galilaeus considered these food items as accidental items. T. zillii considered animal derivatives, copepods, ostracods and molluscans as an accidental item during all four seasons.

\section{DISCUSSION}

According to GAFRD (2005), Tilapias constitute more than third of the total fish production of the River Nile in Egypt during the period 1996-2005 as shown in Fig. (14). Tilapias are the most popularly consumed fish in Egypt (Khallaf and Alne-na-ei, 1987). The study of food and feeding habits will serve in understanding various aspects of fish biology like migration, growth, maturation and spawning etc. So, it was found necessary desirable to study the food and feeding habits of certain commercial fish species (Shehata, 1993a).

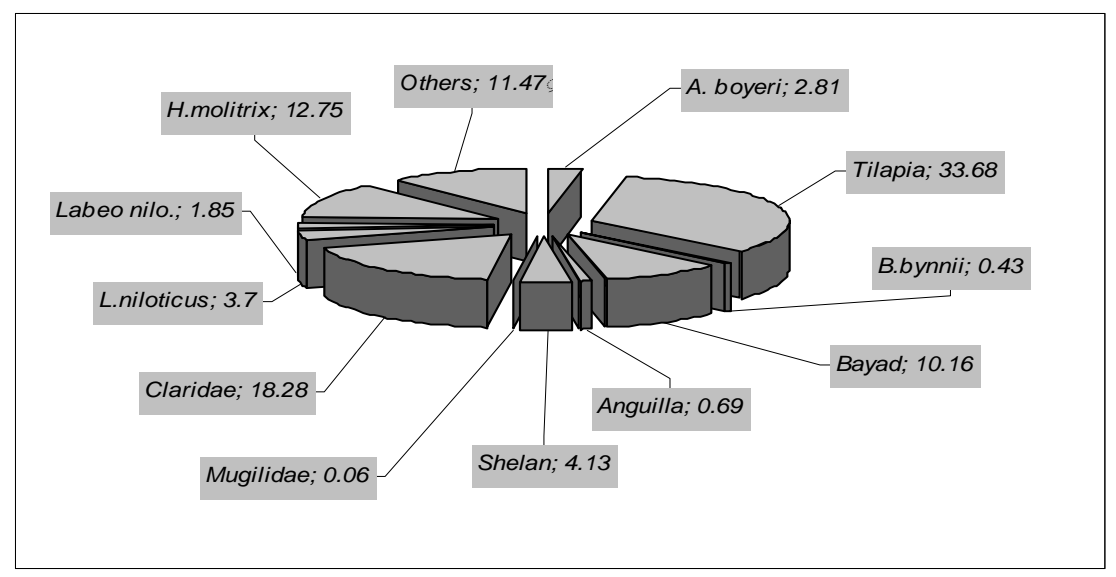

Fig. (14): species composition in the River Nile (GAFRD, 1996- 2005).

Analysis of the stomach contents of O. niloticus, S. galilaeus and T. zillii in Damietta branch of the River Nile revealed that, great diversity in the food items, since green, blue green algae, diatoms, plant tissue, flagellates and detritus constituted food of plant origin, whereas, rotifers, animal derivatives, 
nematode worms, copepods, ostracods, cladocerans and mollusc constituted food of animal origin of the three studied Cichlid fish species. This great diversity of different food items indicates plenty of food types in this branch of River Nile to survive these species. Shalloof and El- Far (2009) recorded that, the major food items in the guts of $O$. aureus, T. zillii and S. galilaeus in Abu- Zaabal Lakes were detritus, diatoms, green algae, animal derivatives, sand particles and rotifers. Negassa and Prabu (2008) stated that macrophytes, detritus, blue green algae, diatoms, green algae, Ceratium, Euglena, and Phacus constituted foods of plant origin, whereas chironomid larvae, Copepoda, Cladocera, Rotifera, Nematoda, fish eggs and fish scales constituted foods of animal origin in the stomachs of $O$. niloticus and T. zillii in Lake Zwai, Ethiopia. Foods of mollusks were also noted in the diet of adult T. zillii in this Lake. Nile tilapia has more diversified diet and can be described as an opportunistic herbivore (Njiru et al., 2004).

Higher plant tissues were higher frequently occurred in the guts of $T$. zillii than the other two species during the four seasons. T. zillii is essentially a macrophyte-feeder. The adult feeds preferentially on aquatic macrophytes and vegetable matter of terrestrial origin (Philipart and Ruwet, 1982), whereas $O$. niloticus is among the many phytoplanktivorous species, and is also known to include animals in its diet consisting of zooplankton and benthic organisms like insect larvae, crustaceans, and mollusks (Balarin and Hatton, 1979).

Results of the two methods of analysis (Index of relative importance, IRI) emphasized the importance of diatoms, blue green and green algae all over the year as major food resources in the stomachs of $O$. niloticus, followed by rotifers and organic detritus. S. galilaeus and T. zillii followed nearly the same behavior as $O$. niloticus, but plant tissue followed blue green and green algae in the diet of $T$. zillii. IRI emphasized the importance of plants (1214.7) as major food resources in the stomachs of O. niloticus (El- Gamal and Ismail, 2005). IRI values established detritus as the most preferable food item in the stomachs of $S$. galilaeus than the other two studied species in which they considered as a secondary item except during spring since $O$. niloticus tend to select it. This may suggested a filter feeding habits of the three studied species. Oso et al. (2006) stated that, O. niloticus and S. galilaeus fed on similar food items. These were mainly macrophytes, Chlamydomonas species and Spirogyra. Other food items include detritus, sand grains and insect parts.

Values of IRI indicate also the importance of food of animal origin in the diets of O. niloticus and S. galilaeus than T. zillii. According to Fryer and Iles (1972), T. zillii has the ability to utilize higher plants as a source of food. This meets the cutting edge of its jaw teeth adapted for such feeding habits.

In the present study, rotifers constituted the main occurred and Percentage of composition analyzed food of animal origin in the three studied species. This indicates the pollution of this branch of River Nile. Aboul-Ezz (2008) mentioned that, rotifers represent one of the most important components 
of the freshwater zooplankton, especially in organically polluted (eutrophic) areas and some rotifers species considered as indicator for domestic pollution as well as trematodes and nematods. Sládećek (1983) reported that, all rotifers are aerobic organisms and occur within limnosaprobity and they can serve as indicators of trophic condition. Rotifers was the most abundant group in Damietta branch with 57 species belonging to 33 genera were recorded and Rotifera was dominated by 5 genera, Keratella, Brachionus, Conchilus, Polyarthra and Asplanchna (El-Bassat, 2002).

In the present investigation, the feeding intensity is strongly influenced by season and corresponding with the time of highest temperature, since the highest stomach fullness occurred during summer for the three studied species and the highest stomach containing food was recorded during spring and summer for S. galilaeus; during autumn and summer for T. zillii, and nearly the same value during autumn and summer for $O$. niloticus. Also, the highest percentage of empty stomachs for the three studied species was recorded during winter. This may be attributed to the effect of the decrease in temperature on the ability of fish to feed in cold season. Species of Tilapia and Sarotherodon are warm-water fishes (Fryer \& Iles 1972). They are most active when the water temperature is high; light penetration is also at its maximum, and high photosynthetic reactions which occur lead to release of enough oxygen to aid high respiratory activity which also leads to high activity in fish (Akintunde, 1982). A constant level of activity by T. zillii in a Nile canal was from April to September, and the highest activity in O. niloticus was from April to July (Khallaf and Alne-na-ei, 1987). Shehata (1993b) concluded that, the fish changed its feeding activity with the change in season and the highest rate of feeding activity of Plectropomus truncatus was during summer, whereas the lowest rate of feeding activity was during winter and this might be due to the effect of turbidity that was produced by rainfall, water temperature, and nonavailability of food in this season.

Selectivity index gives a good idea on the feeding preference or the food selection. Berhaut (1973) suggested three states for this index, when, $\mathrm{S}$ is greater than 0.5 the food item became a preferential one, if it is between 0.1 and 0.5 the food item will be a secondary item and when it is less than 0.1 is called accidental item.

Seasonal variation in selectivity indices of different Cichlid species show that the green, blue green algae and diatoms are the preferable food items (more than 0.5) obtained by O. niloticus and S. galilaeus all over the year, whereas $T$. zillii prefer blue green algae and diatoms during spring and summer only. Organic detritus is the preferable food item in the stomachs of S. galilaeus than the other two studied species in which they considered as a secondary item in importance except during spring since $O$. niloticus prefers to select it. Regarding to the food of animal origin, rotifers are the preferable food in the stomachs of $O$. niloticus during autumn and summer (more than 0.5 ), whereas it 
ranked in the $2^{\text {nd }}$ items of importance all over the year of the other two species (ranged from 0.11- 0.44). Animal derivatives, nematode worms and copepods are the second preferable foods of animal origin in the guts of $O$. niloticus during the four seasons except in winter season, but S. galilaeus considered these food items as an accidental item. T. zillii considered animal derivatives, copepods, ostracods and molluscans as accidental items during all the four seasons.

Generally, food preference of Cichlid fish species studied in Damietta branch of the River Nile varied with season, hence, intraspecific competition between these species were low and did not consume food at random but have the ability to select and choose the preferred food stuff even during different seasons.

In conclusion, Food from plant origin dominates the diet of the three studied species and occurred frequently in more than $60.0 \%$ of examined stomach. Rotifers constituted the main occurred and Percentage of composition analyzed food of animal origin in the three studied species . This indicates the pollution of this branch of River Nile. IRI indicates also the importance of food of animal origin in the diets of $O$. niloticus and S. galilaeus than T. zillii. The feeding intensity is strongly influenced by season since the highest stomach fullness occurred during summer. The three studied Cichlid species did not consume food at random but have the ability to select and choose the preferred natural food items even during different seasons.

\section{REFERENCES}

Abdel- Aziz, N. E. and Gharib, S. M. (2007). Food and feeding habits of round Sardinella (Sardinella aurita) in El- Mex Bay, Alexandria, Egypt. Egypt. J. Aquat. Res., 33: 202- 221.

Aboul-Ezz, S. M. (2008). Zooplankton distribution in Lake Edku during 20032005. Egypt. J. Aquat. Res., 34: 127- 142.

Akintunde, E. A. (1982). Feeding rhythm in relation to changing patterns of $\mathrm{pH}$ in the gut of Sarotherodon galilaeus (Artedi) of Lake Kainji, Nigeria. Hydrobilogia, 97:179- 184.

Akinwumi, F.O. (2001). Food and feeding habits of Tilapia zillii (Pisces: Cichlidae) in Ondo State University fish farm. In: Proc of the $16^{\text {th }}$ annual conference of FISON, pp.: 195- 198.

Bachok, Z. ; Mansor, M. I. and Nordin, R. M. (2004). Diet composition and food habits of demersal and pelagic marine fishes from Terengganu waters, east coast of Peminsular Malaysia, NAGA, Worldfish Center Quarterly, 27: 41- 47. 
Balarin, J. D. and Hatton, T. J. (1979). "Tilapia: A Guide to Their Biology and Culture in Africa", Stirling University Press, Scotland.

Begum, M; M. J. Alam and M. A. Islam (2008). On the food and feeding habit of an estuarine catfish (Mystus gulio Hamilton) in the south-west cost of Bangladesh. University Journal of Zoology, Rajashahi University, 27: 91- 94.

Berhaut, A. (1973). Biologié des stades juveniles de teleosteens Mugilidae, Mugil auratus Risso, 1810; Mugil capito Cuvier, 1829 et Mugil saliens Risso, 1810. Aquaculture, 2: 251- 266.

El-Bassat, R. A. (2002). Ecological studies on zooplankton communities with special reference to protozoa at Damietta Nile branch. Ph.D. Thesis, Fac. Girls, Ain Shams Univ., 116p.

Elewa, A. A and Ali, M. H. H. (1999). Studies of some physico-chemical conditions of River Nile at Damietta branch. Bull. Fac. Sci., Zagazig Univ., 21(2): 89-113.

El Gamal Ael-R. Ismail N. M. (2005). Food composition and feeding habits of some fresh water fishes in various water systems at Abbassa, Egypt, with special reference to snails transmitting diseases. J. Egypt .Soc. Parasitol. , 35 (2):637-52.

Fagade, S.O. (1978). On the biology of Tilapia guineensis (Dumeril) from Lekki Lagoon, Lagos, Nigeria. Nig. J. Sci. 12:73-87.

Fryer, G. \& Iles, T.D. (1972). The cichlid fishes of the Great Lakes of Africa, Their Biology and Evolution, Oliver and Boyd. Edinburgh.

GAFRD (2005) . Annual fishery statistics reports. General Authority for Fish Resources Development, Cairo, Egypt.

Hyslop, E.J. (1980). Stomach contents analysis- A review of methods and their application. Journal of fish Biology, 17: 411- 429.

Ibrahim, S., M. Muhammad, M.A. Ambak, M. Z. Zakaria,A. S. Mamat, M. M. Isa and S. (2003). Stomach contents of six commercially important demersal fishes in the South China Sea. Turkish J. of Fisheries and Aquatic Sciences, 3: 11-16. 
Ikusemiju, K.and Olaniyan,C.I.O. (1977). The food and feeding habits of the cat fish Chrysichthys walkiri(Gunther) and Chrysichthys filamentosus (Boulenger) and Chrysichthys nigrodigitatus(Lacepede) in the Lekki Lagoon, Nigeria. J. Fish Biol., 10:105- 112.

Imevbore, A. M. A. and Bakare, O. (1970). The food and feeding habits of nonecichlid fishes of the River Niger in the Kainji Reservoir area. In Kainji, a Nigerian mane-made Lake. Visser, S. A. (Ed), Vol.1 Ecology, N. I. S. E. R., Ebadan, pp.: 49- 64.

Khallaf, E. A. and Alne-na-ei, A. A. (1987). Feeding ecology of Oreochromis niloticus (Linnaeus) \& Tilapia zillii (Gervais) in a Nile canal. Hydrobiologia, 146: 57- 62.

Laroche, J. L. (1982).Trophic patterns among Larvae of five species of sculpins (family Cottidae) in a marine estuary. Fishery Bulletin NOAA, 80: 827840.

Lopez-Peralta, R. H. and Arcilla, C. A. T. (2002). Diet composition of fish species from the southern continental shelf of Colombia. Naga, 25: 2329.

Mohsin, A. K. M., Ambak, M. A., Said, M. Z. M., Sakiam, M. and Hayase, S. (1987). A study of the feeding habits of fishes in the South Western portion of the South China Sea. In Ekspedisi Matahari '86 (Eds.) A.K.M. Mohsin, M.I.H. Mohamad and M.A. Ambak. Occasional Publication No.4, Faculty of Fisheries and Marine Science, Universiti Pertanian Malaysia, Serdang.

Mohsin, A. K. M., Hayase, S., Ambak, M. A., Said, M.Z.M. and Tanzimuddin Khan, A.H. ( 1988). Feeding habits of fishes found in the EEZ off Sarawak. In Ekspedisi Matahari '87. (Eds.) Mohsin, A.K.M; M. I. H. Mohamad and M. A. Ambak. Occasional Publication No. 8, Faculty of Fisheries and Marine Science, Universiti Pertanian Malaysia, Serdang.

Needham, J. G. \& Needham, P. R. (1962). A Guide to the study of fresh - water biology. Holden-Day, INC., SANFRANCISCO, 107p.

Negassa, A. and Prabu, P. C. (2008). Abundance, food habits, and breeding season of exotic Tilapia zillii and native Oreochromis niloticus L. fish species in Lake Mj. Int. J. Sci. Tech. , 02: 345-359. 
Njiru, M. ; Okeyo- Owuor, J. B.; Muchin, M. and Cowx, I. G. (2004). Shift in feeding ecology of Nile tilapia in Lake Victoria, Kenya. Afric. J. Ecol., 42: $163-170$.

Ogbeibu, A. E. and Ezeunara, P. U. (2005). Studies on the food composition and feeding pattern of fish communities in the Ikpoba River, Southern Nigeria, J. Aqatic Sci., 20:117- 129.

Oso, J. A.; Ayodele, I. A. and Fagbuaro, O. (2006). Food and feeding habits of Oreochromis niloticus (L.) and Sarotherodon galilaeus (L.) in a Tropical Reservoir. World J. of Zool. 1(2) : 118- 121.

Philipart, J. C. L. and Ruwet, J. C. L. (1982). in "The Biology and Culture of Tilapias", (Ed. R. S. V. Pullin and R. H. Lowe-McConnell), Cambridge University Press, London, Ch.1.

Raslan, Y. and Abdelbary, M. R. (2001). Economical and environmental aspects of navigation development in the Nile. Sixth International Water Technology Conference, IWTC 2001, Alexandria, Egypt, 10p.

Shalloof, K. Sh. and El-Far, A. M. (2009). Age,growth and fishery biology of cichlid spp. In Abu- Zaabal Lakes, Egypt.Egypt. J. Aquat. Biol. \& Fish.13 (2): 101- 116.

Shehatta, S. (1993a). Studies on the food and feeding habits of the blackbanded bream Mylio bifasciatus in the Red Sea.Sea. J. Egypt. Ger. Soc. Zool., 10(B), Anatomy\& Embryology: 217- 236.

Shehatta, S. (1993b). Observations on the food and feeding habits of the grouper fish, Plectropomus truncates (Powler and Bean, 1930) North-western of Saudi Arabia, Red Sea. J. Egypt. Ger. Soc. Zool. 10(B), Anatomy \& Embryology:237- 254.

Sládećek, V. (1983). Rotifers as indicator of water Quality. Hydrobiologia, 100: 169-201. 